\title{
Mode of Occurrence and Mineralogy of Northern Khetri Copper Deposits, Jhunjhunu District, Rajasthan
}

\author{
Masood Ahmed*, Mohd Shaif, Farhat Naseem Siddiquie, Rajiullah Khan \\ Department of Geology, Aligarh Muslim University, Aligarh, India \\ Email: ^makhokhar90@gmail.com
}

How to cite this paper: Ahmed, M., Shaif, M., Siddiquie, F.N. and Khan, R. (2018) Mode of Occurrence and Mineralogy of Northern Khetri Copper Deposits, Jhunjhunu District, Rajasthan. Natural Resources, 9, 389-403.

https://doi.org/10.4236/nr.2018.912024

Received: November 22, 2018

Accepted: December 17, 2018

Published: December 20, 2018

Copyright ( $\odot 2018$ by authors and Scientific Research Publishing Inc. This work is licensed under the Creative Commons Attribution International License (CC BY 4.0).

http://creativecommons.org/licenses/by/4.0/

\begin{abstract}
Copper deposits in Khetri copper belt are hosted in the proterozoic sequence of rocks belonging to Ajabgarh group of Delhi supergroup situated in foot hill zone of Aravalli mountain range North-West, India. Khetri copper belt is about $100 \mathrm{~km}$ long NE-SW trending metallogenic province, starting from Singhana in the north to Sangarava in the south. The study area is the northern Khetri copper belt $190 \mathrm{~km} \mathrm{SW}$ of Delhi, the capital city of India. In the present work an attempt has been made to determine the mode of occurrence and nature of mineralization with special emphasis on mineragraphic study of copper ores. The ore bodies are found in the form of multiple lodes regionally but locally in the forms of veins, stringers, dissemination, sporadic, cavity filling and replacement. Enriched mineralized zones are localized along the contact of Alwar and Ajabgarh group. Copper, the main entity in the belt occurs dominantly as sulphides, oxides, carbonates and sulphosalts mineral hosted in pelitic and psammitic rocks. Pyrrhotite, pyrite, magnetite and sphalerite are the other ore mineral associated with the copper ore in a considerable amount. From the textural, structural and multigenerational minerals, mineral assemblage studies, it is assumed that deposit has undergone metamorphism and multi-stage mineralization. Replacement has a profound influence on mineralization in the northern Khetri copper deposits.
\end{abstract}

\section{Keywords}

Copper Ores, Mineralogy, Khetri, Rajasthan

\section{Introduction}

Copper is most important base metal used in various industries due to its high 
conductivity, strength and durability. Its crustal abundance is $60 \mathrm{ppm}$. It occurs in native form but mostly in association with sulphur, oxygen, carbonates and other transition metals as sulphosalts. Khetri copper belt is a $100 \mathrm{~km}$ long NE-SW trending located in NDFB of Aravalli Mountains. This belt is named after Khetri town where most enriched mineralization is traced. Khetri copper belt is the largest copper ore repository in India. This study is constrained to the northern part of Khetri copper belt. The important localities in the northern part of the area are Madhan-Kudhan (Khetri) $\left(28^{\circ} 4^{\prime} 15^{\prime \prime}: 75^{\circ} 47^{\prime} 25^{\prime \prime}\right)$, Kolihan (28 : $\left.75^{\circ} 44^{\prime}\right)$, Chandamari $\left(27^{\circ} 56^{\prime}: 75^{\circ} 46^{\prime}\right)$ and many other described by [1]. The present study is pertained to these deposits. At present Kholian and Madhan-kudhan (Khetri Mine) are the only two underground productive mines in the study area. The principal sulfide ore minerals in the northern Khetri copper deposits are chalcopyrite, pyrrhotite, and pyrite [2]-[9] and [10]. Copper minerals in subordinate amount include cubanite, tetrahedrite, azurite, malachite and chalcocite etc. Other associated ore minerals are magnetite, sphalerite, ilmenite, arsenopyrite, molybdenite, cobaltite, pentlandite, marcasite, zircon, mackinawite and sulphosalts. Though the area is under intensive investigations from a long time, the complete mineralogical appraisal of copper in these deposits and a comparative description are lacking. In the present work an attempt has been made to lay emphasis on the mode of occurrence and mineralogy of $\mathrm{Mu}$ dan-Kudan (Khetri), Kolihan and Chandmari copper deposits.

\section{Geology and Structure of the Study Area}

Regionally, the study area is a part of Delhi Supergroup. [11] divided this Supergroup into South Delhi Fold Belt (SDFB) and North Delhi Fold Belt (NDFB). The division based on the purported diachronous nature of sedimentation and granite magmatism in the two belts. According to [12] and [13] strongly contesting proposed that the rocks of the Delhi Supergroup were deposited synchronously in different basins having dissimilar evolutionary histories. The NE-SW oriented Khetri Copper Belt (KCB), a part of the NDFB, is located in the northern most part of the Aravalli-Delhi mountain range NW India (Figure 1(a)). This copper belt extends for about $100 \mathrm{~km}$ from Singhana (Jhunjhunu district) in the NE to Sangarva (Sikar district) in the SW. The Kantli Fault occupied by Kantli river divides the Khetri copper belt into the North Khetri Copper Belt (NKCB) and the South Khetri Copper Belt (SKCB) [14]. The northern part of the Khetri copper belt, study area of the present work (Figure 1(b)) is composed of arenaceous and argillaceous metsedimentary rocks of Delhi supergroup are associated with mafic volcanic rocks belonging to Alwar and Ajabgarh Group are exposed [7] [13] [15] [16] [17]. Mineralization in the study area is constrained mainly in the Ajabgarh series of rocks with most enriched zones localized along the contact of Ajabgarh and Alwar series of rock units [2] [7]. The metasedimentary rocks in the $\mathrm{NKCB}$ are underlain by $\sim 1.82 \mathrm{Ga}$ granitic rocks and $\sim 1.70 \mathrm{Ga}$ A-type granites [18] [19] [20]. The metasedimentary rocks in the 

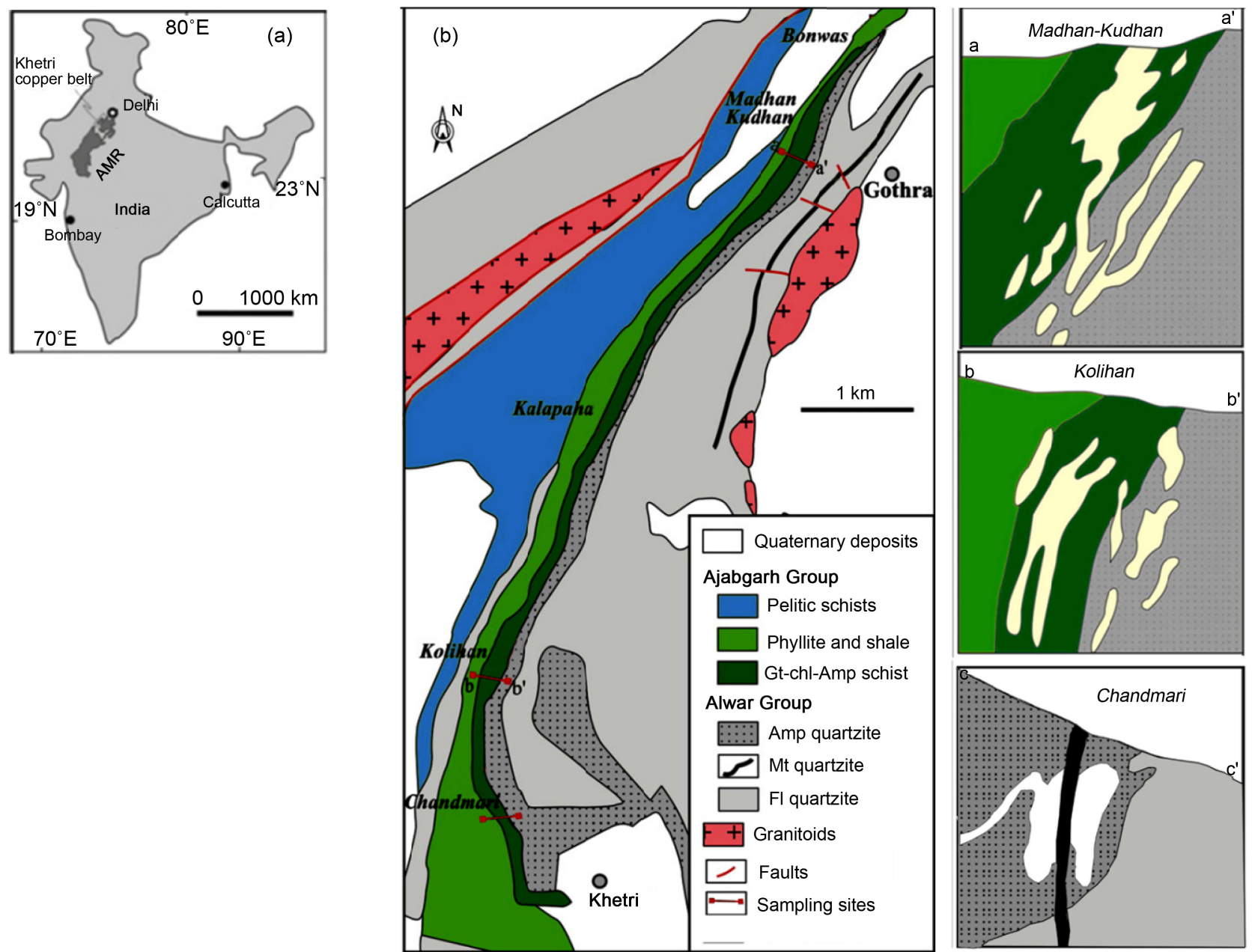

Figure 1. (a) Location of Khetri copper belt in Aravalli mountain range in the map of India. (b) Geological map of study area showing the sample collection sites (modified after [9]. a-a', b-b'and c-c' are the cross sections of Mudhan-Kudhan (Khetri), Kolihan and Chandmari Ore bodies (after [26]).

eastern part of the NKCB are inferred to have been deposited under shallow marine conditions inferred from the preserved sedimentary and syn-sedimentary deformation structures like ripple marks current bedding mud cracks, load cast and convolute laminations etc. while those in the western side are of relatively deep marine origin [7] and [21]. The rocks of the NKCB are multiply deformed and polymetamorphosed [14] [16] [22] [23] [24]. Three generations of folds, F1, $\mathrm{F} 2$ and $\mathrm{F} 3$ are identified, of which F1 and F2 are co-axial in many places, and the axial trace of F3 is at high angle with the former [2] and [24]. Three different phases of deformation have been recognised. The temperature and pressure conditions during $\mathrm{M} 1$ and $\mathrm{M} 2$ have been inferred to be $550^{\circ} \mathrm{C} \pm 50^{\circ} \mathrm{C}$ and $550^{\circ} \mathrm{C}$ - $650^{\circ} \mathrm{C}$ with pressure range of $3-5 \mathrm{~Kb}$ during the M1 and M2 phases, respectively [7] [22] [23]. The $M_{3}$ retrograde event marked by chloritization, biotization and sericitization at the garnet, amphibole, carderite and andalusite [1]. The last metamorphic event has been dated at 950 - 910 Ma through chemical dating of monazite [19] and [25]. 


\section{Methodology}

About 50 samples of ore were collected from Mudhan-Kudhan (Khetri), Kolihan and Chandmari mine. The collected samples were megascopically examined and from each collected sample polished block was prepared in accordance of [27] in the Department of Geology AMU., Aligarh. The final polished blocks studied in reflected light under the ore microscope in the Department of Geological Sciences, Jadavpur University. Six selected samples of ores from different locations were powdered to 200 mash size. An X-ray diffraction study was carried out in the Department of Mechanical Engineering AMU, Aligarh. The peaks were observed from $5^{\circ}$ to $90^{\circ}$ with step size of $0.05 /$ Second. Raw data is interpreted in X-pert High Score Plus and finally plotted in Origin 8.5.

\section{General Statement of Mines}

\subsection{Madhan-Kudhan (Khetri) Deposit}

Madhan-Kudhan mine is the largest underground metal mine in the country. Mine workings extend over a strike length of about $3.6 \mathrm{~km}$. The ore bodies occur as series of discontinuous layers sub-parallel lodes (Figure 1(a'') cross section). The copper ore is found to occur as veins, stringers, fracture filling and disseminated type in garnetiferous-quartz-chlorite schist and amphibole quartzite (Figure 2(a) and Figure 2(c)). The economic concentration of $\mathrm{Cu}$ at Madhan-Kudhan (Khetri) is around 66 million tons @1.12-1.71\% Cu [26].

\subsection{Kolihan Deposit}

The total mine development work has been carried out in mine is $1,03,123.20$ meters and the mine has produced 189, 53,441 tonnes @1.37\% Cu. till 31.03.2013 [28]. The economic concentration of ore at Kolihan-Chandmari mine is around 40 million tons @ $1.12 \%-1.71 \% \mathrm{Cu}, 0.2-0.6 \mathrm{~g} / \mathrm{t} \mathrm{Au}$ and $2-8 \mathrm{~g} / \mathrm{t} \mathrm{Ag}$ [26]. This is the first mine in India which was developed on trackless and ramp system of mining. The Kolihan Copper Mine has been developed over a strike length of 700 metres and has eight levels at vertical interval of 60 metres. Ore bodies occur similar to Madhan-Kudhan (Khetri) mine in the form of lodes (Figure 1(bb') Cross section) constrained to garnetiferous-quartz-chlorite schist and amphibole bearing feldspathic quartzite (Figure 2(b) \& Figure 2(d)). The rock exposures around the Kolihan mine shows traces of malachite and azurite. The surface area of Kolihan mine is subsiding due to the presence of highly sheared phyllite bed along the lodes of ore bodies.

\subsection{Chandmari Deposit}

Chandmari area (Latitude $26.000 \mathrm{~N}$; Longitude $75.046 \mathrm{E}$ ) is located $1 \mathrm{~km}$ north west of Khetri town. The rock formations of the area belong to the Alwar and Ajabgarh groups of the Delhi Supergroup. The main rock types outcropping in the area are andalusite-biotite-quartz schist, phyllite, amphibole quartzite, talc-magnetite-amphibole-schist and felspathic quartzite [29]. Quartz veins and 


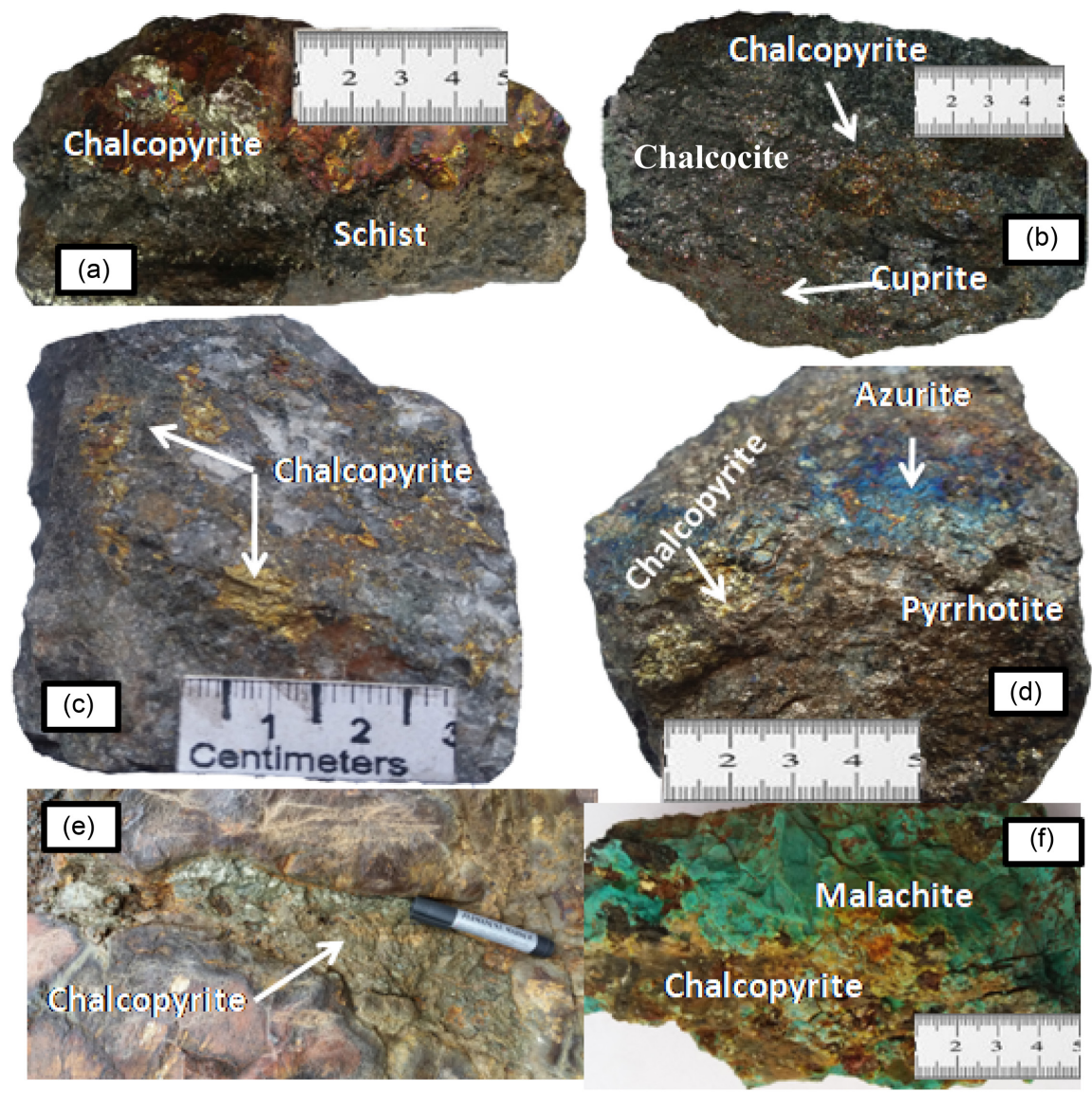

Figure 2. Photographs showing mode of occurrences and mineral associations from northern khetri copper deposits Jhunjhunu dist. Rajasthan. (a) shows sharp contact of chalcopyrite with host rock, (b) shows chalcopyrite and cuprite in garnetiferous quartz chlorite schist, (c) showing sporadic occurrences of chalcopyrite in amphibole quartzite, (d) showing the association of chalcopyrite with pyrrhotite and azurite, (e) shows vein of chalcopyrite in feldspathic quartzite, (f) shows the alteration of chalcopyrite into malachite.

metabasic rocks are the common intrusives. In Chandmari mine ore body occur as lode (Figure 1(cc') Cross section) mainly localized in feldspathic quartzite and amphibole quartzite. The mineralisation is in the form veins (Figure 2(e)) disseminations and stringers of chalcopyrite and pyrrhotite. The other sulphide minerals are chalcocite, pyrite, magnatite and sphalerite. Chamdmari open pit mine is abandoned since 2002 therefore the chalcopyrite and pyrrhotite veins in the bench and ramp faces are weathered and transformed to secondary minerals (Figure 2(f)) The area has undergone intense folding, which has resulted in frequent changes in the strike of the formations in the area.

\section{Mode of Occurrences}

Geologically copper mineralization is reported in the Alwar and Ajabgarh series of rocks of Delhi supergroup [1] [15] and [7] the extent of mineralization is relatively wide in the ajabgarhseries. The Copper ore deposits of Khetri have been 
reported to occur all along the belt with highest potential in the khetri town in the northern part of the belt. In most places their presence was indicated at the surface by the occurrence of gossans consisting of oxidized ores of copper and iron having stains of malachite and azurite, boxwork of lenticular limonitic or red ochre bands [1] and [30]. Major copper ores, association and mode of occurrence in cross sections and hand specimens are shown in (Figures 2(a)-(f)). Mineralization in the khetri area is of high grade and occurs as massive zones, stock works, disseminations and lenses \& veins across the lithologies. The chief ore minerals belonging tosulphides; chalcopyrite, $\left(\mathrm{CuFeS}_{2}\right)$ chalcocite $\left(\mathrm{Cu}_{2} \mathrm{~S}\right)$, bornite $\left(\mathrm{Cu}_{5} \mathrm{FeS}_{4}\right)$, covellite $(\mathrm{CuS})$, and tetrahedrite $\left.(\mathrm{Cu}, \mathrm{Fe})_{12} \mathrm{Sb}_{4} \mathrm{~S}_{13}\right)$, oxide; cuprite $\left(\mathrm{Cu}_{2} \mathrm{O}\right)$, Carbonates; azurite $\left(\mathrm{CuCO}_{3}\right)$ and malachite $\mathrm{Cu}_{2} \mathrm{CO}_{3}(\mathrm{OH})_{2}$ etc constitute the Khetri copper deposits. [31] described the compositional variation in $\mathrm{wt} \%$ of major elements in different ore minerals found in Khetri copper belt. The textural and structural observations on polished blocks shows replacement type of mineralization (Figures 3(a)-(f)). The bulk of mineralization is constrained to garnetiferous-quartz-chlorite schist in the northern Khetri copper belt [7]. Generally the enriched mineralized zones are located along the contact Alwar and Ajabgarh Series in the Northern Khetri Copper Belt (Figure 1(b)). The mineralization, however, is not confined to any particular rock type of either of the two series. Local as well as regional shift in mineralization is common in this belt. Passing further south, the occurrence of copper has also been reported from the biotite-schist, phyllites and amphibolites [32].

\section{Minerology of Ore}

The copper ores samples were collected from the Madhan-Kudhan (Khetri), Kolihan and Chandamari mines of the northern part of Khetri Copper Belt. The collected samples are megascopically examined and chalcopyrite, chalcocite, malachite, bornite, covellite, tetrahedrite, azurite, and cuprite ore minerals are identified (Figures 2(a)-(f)), which are validated through X-ray diffraction studies (Figures 4(a)-(f)) and optical investigation on polished blocks in reflected light (Figures 3(a)-(f)). Other metallic mineral associated in copper ore are; pyrite, pyrrhotite, sphalerite, magnetite/hematite, marcasite, mackinwite, pentalandite, cinnabar, calaverite, gold and different sulphosalts.

\subsection{Chalcopyrite}

Chalcopyrite is the main copper ore in the Khetri copper belt. Chalcopyrite occurs in all the samples collected from different location of NKCB. It has brassy to golden yellow colour with green tinged black streak, brittle in nature, hardness of 3.5 to 4 and specific gravity is around 4.1 to 4.3 . It occurs in the forms of veins, disseminations, and stringers commonly associated with bornite, chalcocite, azurite, pyrrhotite and pyrite. It is confused with pyrite but it can be easily distinguished from pyrite due to its iridescent tarnish appearance (Figure 2(a)) and hardness. Chalcopyrite occurs either in massive form or as fine grains 

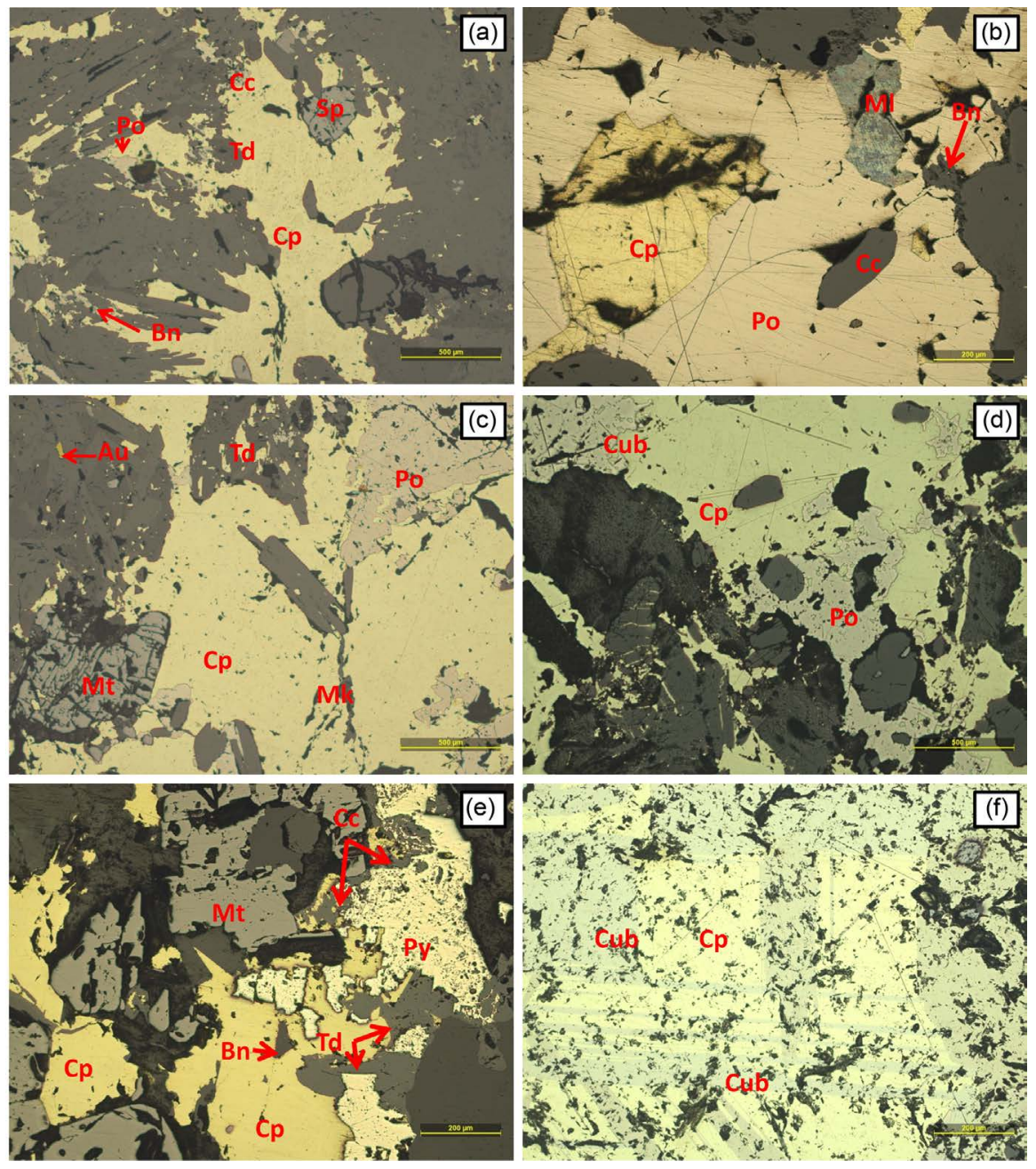

Figure 3. Microphotographs of ore samples collected from Madhan-Kudhan (Khetri), Kolihanchandmari mine (a) shows massive and fine grained chalcopyrite (Cp) with tetrahedrite $(\mathrm{Td})$, chalcocite $(\mathrm{Cc})$ and bornite $(\mathrm{Bn})$ along the boundary of chalcopyrite. $(\mathrm{b})$ shows chalcopyrite, chalcocite, malachite $(\mathrm{Ml})$ and bornite enclosed in massive pyrrhotite (Po). (c) shows relicts of pyrrhotite, tetrahedrite and mackinwite (Mk) in chalcopyrite background mass. (d) shows massive chalcopyrite with relicts of chalcocite, bornite, pyrrhotite \& cubanite (Cub) and veins of chalcopyrite traversing schistose planes and fracture fillings. (e) shows Chalcopyrite associated with pyrite (Py), chalcocite, tetrahedrite and sphalerite (Sp) \& magnetite (Mt) traped in silicates. (f) shows two set of cubanite lamellae in chalcopyrite.

interlocked with pyrrhotite in quartzitic and silicified rocks, or as veins traversing schistose planes or associated with quartz veins (Figure 3(d)). It shows yellow to brassy yellow colour and occur as coarse grain anhedral crystal in polished blocks (Figure 3). Chalcoyprite has exsolution threads of mackinawite. [5] describe the two generation of chalcopyrite from the textural study of pre minerals in Kolihan mine. Chalcopyrite of the first generation occurs as disseminated grains in quartzites and schist while Chalcopyrite of the second generation is massive in occurrence and is associated with hexagonal pyrrhorite (Figure 3(b) \& Figure 3(c)). 


\subsection{Chalcocite}

Chalcocite is opaque and dark-gray to black with a metallic lustre and shiny black to lead gray lustre. It has a hardness of $2.5-3$ and specific gravity around 5.5 - 5.8. Chalcocite is found in the samples collected from the deeper levels of the underground madhan-Kudhan (Khetri) and Kolihan mines and did not traced in samples collected from Chandmari area. Chalcocite is reported as secondary mineral formed from the alteration of other minerals like chalcopyrite, pyrite, covellite and bornite. It occurs as bluish white colour, fine grain aggregate, most commonly along the boundry of chalcopyrite grains (Figures $3(a)-(c))$.

\subsection{Bornite}

Bornite is brown to black with a typical purplish to bluish tarnish, a reddish bronze colour on freshly broken surfaces. It is opaque with metalliclustre and greyish black streak. Its striking iridescence gives it the nickname peacock copper or peacock ore. Hardness is around 3 and specific gravity is approximately 4.9 to 5.3 . Good crystals are rare and thus bornite is commonly known as simply a massive ore mineral. Bornite has pinkish brown to orange colour, weak anisotropism and slight bireflectence which is visible on grain boundaries. It shows a common association with chalcopyrite (Figure $3(\mathrm{a})$ ).

\subsection{Cubanite}

Cubanite is bronze to brass yellow colour in appearance. It has metallic lustre with black colour streak. Its hardness varies from 3.5 - 4 while specific gravity is 4.0 - 4.2. It commonly occurs as elongated to thick tabular crystals. [5] described three types of cubanite in the Kolihan mine as isometric, tetragonal, and orthorhombic cubaniteon the basis of optical properties. Isotropic cubanite is similar to cubanite II of [33]. The first two varities are similar to chalcopyrite. The exsolution lamellae of cubanite are commonly found in chalcopyrite. One or two set of cubanite lamellae (Figure 3(f)) exsolve along (III) planes is well known [34] [35] and [36].

\subsection{Tetrahedrite}

Tetrahedrite is a copper antimony sulfosalt mineral which is isotropic and ligh-grey in colour. It is the antimony end member of the continuous solid solution series with arsenic-bearing tennantite. High peaks of tetrahedrite are observed in the X-ray diffraction studies of copper ores. Fe- and Zn-bearing tetrahedrite-tennantite solid solutions are common constituents of polymetallic base metal sulfide deposits [37] [38] [39] (Wu and Petersen, 1977; Einaudi, 1977; Knight, 1977). Tetrahedrite is found to be associated with chalcopyrite in replacement relationship and generally found along the boundaries of chalcopyrite and pyrrhotite (Figure 3(c) \& Figure 3(e)) as fine aggregate or crystal intergrowth. In on sample it is documented as replacing arsenopyrite and infillings 
along the fractures in arsenopyrite.

\subsection{Azurite}

Azurite is transparent to translucent, azure blue coloured, soft copper ore. It has pale blue Streak and vitreous to sub-adamantine lustre. Hardness ranges from 3.5 - 4 with specific gravity around 3.70 to 3.90 . It was reported by [40]. It is a secondary mineral produced by weathering of primary sulphides and found in the oxidized zone of copper ore deposits. It occurs in association with chalcopyrite and pyrrhotite (Figure 2(d)). Its individual specimen is not found but can be visualise in hand specimens in association with chalcopyrite, chalcocite and pyrrhotite.

\subsection{Malachite}

Malachite is a green copper carbonate hydroxide mineral with a chemical composition of $\mathrm{Cu}_{2}\left(\mathrm{CO}_{3}\right)(\mathrm{OH})_{2}$ [41]. Malachite is rarely found as a crystal. Non-crystalline specimens are opaque, are bright green in colour, usually with a dull to earthy lustre. Malachite has high specific gravity that ranges from 3.6 to 4.0 and hardness ranges from 3.5 to 4.0. it generally occur as botryoidal coatings and as a secondary mineral transformed from other sulphides (Figure 2(f) and Figure 3(b)). It occurs in association with chalcopyrite, pyrite, and azurite in the samples collected from Kolihan and Chandmari copper mine.

\subsection{Cuprite}

Cuprite is a minor ore of copper occurring as secondary mineral in the oxidized zone of copper sulfide deposits. It frequently occurs in association with native copper, azurite, chrysocolla, malachite and a variety of iron oxide [42]. It has distinctive red colour, sub-metallic to brilliant adamantine lustre, about 3.5 to 4 hardness and a relatively high specific gravity of about 6.1. It is found associated with chalcopyrite and chalcocite in garnetiferous quartz chlorite schist (Figure 2(b)).

\section{Results and Discussion}

Mineralization in the khetri copper deposits occurs as multiple lodes of varying shapes and dimensions are localized in medium grade metamorphosed pelitic and psamitic rock units [2] and [7]. A polymetallic type of mineralization has been found in the study area and IOCG type of mineralization is ascertained due to its characters analogous to IOCG-type deposits of the world (Knight et al., 2002). According to [43] the $\mathrm{Cu}-(\mathrm{Au})$ mineralization is contemporary with regional Ca-Na metasomatism in the Khetri Copper Belt, which was accompanied by significant mobilization of certain metals and may facilitate the formation of $\mathrm{Cu}-\mathrm{Au})$ ore. Khetri area has the highest potential for copper ores and slag heaps at different location representing the traces of ancient copper mining in the area. Ore body in the study area occurs regionally as lodes, hand specimens and cross 
sections as veins, stringers, disseminations and sporadic. Khetri copper deposits are sulphide deposits with minor proportion oxides, carbonates and silicates ore minerals. The general features of ore minerals in hand specimens and mineral assemblage, nature of mineralization and mode of occurrence documented shows a multistage of mineralization. The complete mineral assemblage observed in hand specimens, polished blocks and X-ray diffraction studies (Figures 4(a)-(f)) of the ore samples is tabulated in (Table 1).
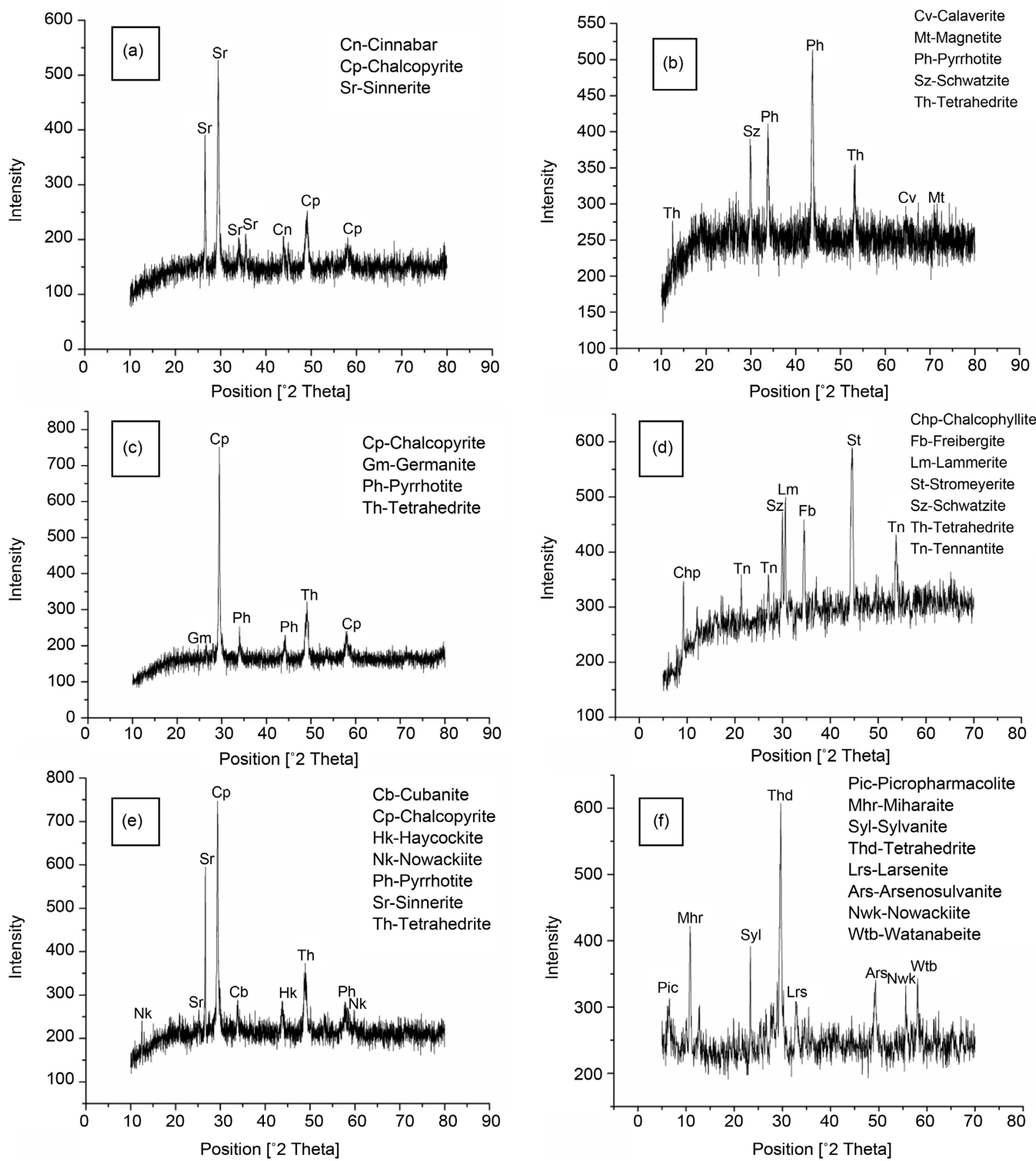

Figure 4. (a)-(f) show $2 \theta$ position of various copper minerals. (a) \& (b) from chandmari mine, (c) \& (d) from Kolihan mine and (e) \& (f) from Madhan-Kudan (Khetri) mine northern Khetri copper belt, Jhunjhunu district, Rajasthan. 


\section{Paragenesis}

The main ore minerals are chalcopyrite, pyrrhotite and pyrite. The textural relations observed andearlier study [5] it appears that there are two principle generations of sulfide minerals and are referred here as hydrothermal phase I and II. The dominant sulfide minerals in both the phases of mineralization are chalcopyrite and pyrrhotite. In addition to these two minerals there are other minerals formed by exsolution.

The two phases of mineralization are separated by an interval manifested by invasion of carbonate-bearing solutions, during which pyrrhotite of the first generation has been converted into pyrite and marcasite [5]. Due to the complex deformational history, multiphase mineralization, missing of certain phases locally as well as regionally variable controls on mineral localization and diverse nature of mineralization, complete paragenetic sequence cannot be developed for the northern Khetri copper deposits. However the different assamblages observed are tabulated in Table 1.

Table 1. Mineral assemblage of ore minerals in Mudhan-Kudhan (Khetri), Kolihan and Chandmari mine and various associations observed in the polished blocks and X-ray diffraction studies.

\begin{tabular}{|c|c|}
\hline & 1. Chalcopyrite + Pyrrhotite + Pyrite + Bornite + Chalcocite \\
\hline \multirow{9}{*}{$\begin{array}{l}\text { Mudhan-Kudhan } \\
\text { (Khetri) Deposit }\end{array}$} & 2. Pyrrhotite + Chalcopyrite + Pyrite + Magnetite \\
\hline & 3. Chalcopyrite + Pyrrhotite + Magnetite + Pyrite + Chalcosite \\
\hline & 4. Chalcopyrite + Pyrrhotite + Cubanite + Cuprite + Chalcosite \\
\hline & 5. Pyrrhotite + Chalcopyrite + Chrysocolla + Pyrite \\
\hline & Associated ore minerals: Haycockite, Nowackiite, Sinnerite, \\
\hline & Tetrahedrite, Picropharmacolite, Miharaite, \\
\hline & Sylvanite, Larsenite, Arsenosulvanite, Watanabeite, \\
\hline & Sphalerite, Mackinwaite, Cobaltite, \\
\hline & Pentalandite, Marcasite. \\
\hline \multirow{10}{*}{ Kolihan Deposit } & 1. Chalcopyrite + Pyrrhotite + Pyrite \\
\hline & 2. Pyrrhotite + Chalcopyrite + Chalcosite + Covelite \\
\hline & 3. Pyrrhotite + Chalcopyrite + Ilmanite + Pyrite \\
\hline & 4. Chalcopyrite + Pyrrhotite + Arsenopyrite + Pyrite \\
\hline & 5. Chalcopyrite + Pyrrhotite + Sphalerite + Cobaltite \\
\hline & 6. Chalcopyrite + Pyrrhotite + Pyrite + Arsenopyrite + Magnetite \\
\hline & Associated ore minerals: Germanite, Valleriite, Sphalerite, \\
\hline & Mackinwaite, Cobaltite, Pentalandite, Marcasite, Tetrahedrite, \\
\hline & Chalcophyllite, Freibergite, Lammerite, Stromeyerite, \\
\hline & Schwatzite, Tennantite. \\
\hline \multirow{6}{*}{ Chandmari Deposit } & 1. Chalcopyrite + Pyrrhotite + Pyrite \\
\hline & 2. Pyrrhotite + Chalcopyrite + Cubanite + Chalcosite \\
\hline & 3. Chalcopyrite + Chalcosite + Pyrrhotite \\
\hline & Associated ore minerals: Magnetite, Cinnabar, Sinnerite, \\
\hline & Calverite, Tetrahedrite, Covellite, Azurite, Malachite, \\
\hline & Schwatzite, Chrysocolla, Cobaltite, Sphalerite. \\
\hline
\end{tabular}




\section{Conclusion}

In the Khetri deposits mineragraphic and XRD study of ores reveals a diverse nature of mineralization. Ore bodies occur as multiple lodes of varying size and shape. Mineralization is not constrained to any single litho-unit. The structures like joints, faults and fractures have dominant control over mineralization. Ore minerals occur as veins, stringers, disseminations, stock works and fracture fillings. Chalcopyrite is the main copper ore in the Khetri copper deposits. Cubanite, chalcocite, covalite, azurite, tetrahedrite, malachite and numerous Copper sulphosalts are also found associated with chalcopyrite. The mode of occurrence of ore and various textures and structures in the NKCB reveals that the deposit is formed as a result of hydrothermal solution and later on altered by metamorphism. Copper deposits in the northern part of the belt are associated with number of other metal ores of $\mathrm{Co}, \mathrm{Zn}, \mathrm{Ni}, \mathrm{Ag}$, Au etc.

\section{Acknowledgements}

The author is grateful to Prof. Syed Ahmed Ali, Chairman Department of Geology, AMU Aligarh and Prof. Subir Mukhopadhaya from Jadavpur University for ore microscopy. The field assistance of Mr A.J. Khan, Mr. Harsh Dev and Mr. N.K. Rajpurohit appreciated. Chairman Department of Mechanical Engineering for providing X-ray diffraction facility.

\section{Conflicts of Interest}

The authors declare no conflicts of interest regarding the publication of this paper.

\section{References}

[1] Roy Chowdhury, M.K. and Das Gupta, S.P. (1965a) On the Nature of Geology and Mineralisation in the Khetri Copper Belt, Rajasthan. Proc. Nat. Inst. Sci., 31, 188-198.

[2] Roy Chowdhury, M.K. and Das Gupta, S.P. (1965b) Ore-Localization in the Khetri Copper Belt, Rajasthan, India. Economic Geology, 60, 69-88. https://doi.org/10.2113/gsecongeo.60.1.69

[3] Mukherjee, A.K. (1966) Study of Ore Minerals from Kolihan Section of Khetri Copper Belt, Jhunjhunu Dt.; Rajasthan. Sci. Cul., 32, 250-254.

[4] Mukherjee, A.D. (1972) Study of a Copper-Iron Sulphide Mineral (Cu 0.13 Fe 0.92 S 1.00) from the Sulphide Ores of Kollhan Section, Khetri Copper Belt, Rajasthan. Geological Society of India, 13, 185-189.

[5] Rao, N.K. and Rao, G.V.U. (1968) Ore Microscopic Study of Copper Ore from Kolihan, Rajasthan, India. Economic Geology, 63, 277-287.

https://doi.org/10.2113/gsecongeo.63.3.277

[6] Deb, S. and Mukherjee, A.D. (1969) Mackinawites from Madhan-Kudhan and Kolihan Sections of Khetri Copper Belt, Rajasthan. Proceedings of the National Academy of Sciences, India, 35A, 533-541.

[7] Sarkar, S.C. and Dasgupta, S. (1980) Geologic Setting, Genesis and Transformation of the Sulphide Deposits in the Northern Part of the Khetri Copper Belt, Rajasthan, 
India-An Outline. Mineral. Deposita, 15, 117-137. https://doi.org/10.1007/BF00206508

[8] Mukherjee, A.D. and Sen, P.P. (1991) Compositional Variations in Mackinawites from the Chandmari Mine of Khetri Copper Belt, Rajasthan. Journal of the Geological Society of India, 38, 96-100.

[9] Chen, W.T., Zhou, M.F., Li, X., Gao, J.F. and Hou, K. (2015) In-Situ LA-ICP-MS Trace Elemental Analyses of Magnetite: $\mathrm{Cu}-(\mathrm{Au}, \mathrm{Fe})$ Deposits in the Khetri Copper Belt in Rajasthan Province, NW India. Ore Geology Reviews, 65, 929-939. https://doi.org/10.1016/j.oregeorev.2014.09.035

[10] Baidya, A.S., Sen, A. and Pal, D.C. (2018) Textures and Compositions of Cobalt Pentlandite and Cobaltian Mackinawite from the Madan-Kudan Copper Deposit, Khetri Copper Belt, Rajasthan, India. Journal of Earth System Science, 127, 56. https://doi.org/10.1007/s12040-018-0954-Z

[11] Sinha-Roy, S. (1984) Precambrian Crustal Interaction in Rajasthan, NW India. Indian Journal of Earth Sciences, 11, 84-91.

[12] Roy, A.B. and Kataria, P. (1999) Precambrian Geology of the Aravalli Mountain and Neighbourhood: Analytical Update of Recent Studies. In: Kataria, P., Ed., Seminar on Geology of Rajasthan: Status and Perspective, Mohanlal Sukhadia University, Udaipur, 1-56.

[13] Roy, A.B. and Jakhar, S.R. (2002) Geology of Rajasthan (Northwest India) Precambrian to Recent. Scientific Publishers, Jodhpur, 421.

[14] Gupta, P., Guha, D.B. and Chattopadhyay, B. (1998) Basement-Cover Relationship in the Khetri Copper Belt and the Emplacement Mechanism of the Granite Massifs, Rajasthan. Journal of the Geological Society of India, 52, 417-432.

[15] Heron, A.M. (1923) Geology of Western Jaipur. Record Geological Survey of India, 54, 345-397.

[16] Dasgupta, S.P. (1968) Structural History of Khetri Copper Belt, Jhunjhunu and Sikar Districts, Rajasthan. Memoirs of the Geological Survey of India, 98, 1-170.

[17] Singh, S.P. (1988) Stratigraphy and Sedimentation Pattern in the Proterozoic Delhi Supergroup, Northwestern India. Memoirs Geological Society of India, 7, 193-206.

[18] Kaur, G. and Mehta, P.K. (2007) Geochemistry and Petrogenesis of Jasrapura Granitoids, North Khetri Copper Belt, Rajasthan: Evidence for Island Arc Magmatism. Journal of the Geological Society of India, 69, 319-330.

[19] Kaur, P., Chaudhri, N., Biju-Sekhar, S. and Yokoyama, K. (2006) Electron Probe Microanalyser Chemical Zircon Ages of the Khetri Granitoids, Rajasthan, India: Record of Widespread Late Palaeoproterozoic Extension-Related Magmatism. Current Science, 90, 65-73.

[20] Kaur, P., Chaudhri, N., Hofmann, A.W., Raczek, I., Okrusch, M., Skora, S. and Baumgartner, L.P. (2012) Two-Stage, Extreme Albitization of A-Type Granites from Rajasthan, NW India. Journal of Petrology, 53, 919-948. https://doi.org/10.1093/petrology/egs003

[21] Das Gupta, S. (1978) Sedimentary Structures in the Precambrian Delhi Supergroup Rocks and Their Significance. Indian Journal of Earth Sciences, 5, 177-182.

[22] LAl, R.K. and Shukla, R.S. (1975) Low-Pressure Regional Metamorphism in the Northern Portion of the Khetri Copper Belt, Rajasthan, India. Neues Jahrbuch für Mineralogie Abhandlungen, 124, 294-325.

[23] Lal, R.K. \& Ackermand, D. (1981) Phase Petrology and Polyphase Andalusite-Sillimanite Type Regional Metamorphism in Pelitic Schist of the Area around 
Akwali, Khetri Copper Belt, Rajasthan, India. Neues Jahrbuch fur Minineralogie, Abhandlungen, 141, 161-185.

[24] Naha, K., Mukhopadhyay, D.K. and Mohanty, R. (1988) Structural Evolution of the Rocks of the Delhi Group around Khetri, Northeastern Rajasthan. In: Roy, A.B., Ed., Precambrian of the Aravalli Mountain, Geol. Soci. Ndia, Mem. No. 7, Rajasthan, 207-245.

[25] Pant, N.C., Kundu, A. and Joshi, S. (2008) Age of Metamorphism of Delhi Supergroup Rocks-Electron Microprobe Ages from Mahendragarh District, Haryana. Journal of the Geological Society of India, 72, 365-372.

[26] Knight, J., Lowe, J., Joy, S., Cameron, J., Merrillees, J., Nag, S., Shah, N., Dua, G. and Jhala, K. (2002) The Khetri Copper Belt, Rajasthan: Iron Oxide Copper-Gold Terrane in the Proterozoic of NE India. In: Porter, T.M., Ed., Hydrothermal Iron Oxide Copper-Gold and Related Deposits: A Global Perspective, 2, PGC, Adelaide, 321-341.

[27] Ineson, P.R. (2014) Introduction to Practical Ore Microscopy. Routledge, New York. https://doi.org/10.4324/9781315841205

[28] Kumar, D., Bahuguna, P.P., Villuri, M.V.G., Alam, M.S. and Panigrahi, D.C. (2014) Subsidence Study for Kolihan Copper Mine at Khetri Copper Complex, Rajasthan.

[29] MECL (1995) Geological Report on Exploration for Copper Ore in Chandmari Intervening Block, Khetri Copper Belt, District-Jhunjhunu, Rajasthan.

[30] Zafar, M. (1971) Contribution to Geochemistry of the Khetri Copper Belt, District Jhunjhuno, Rajasthan, India. Doctoral Dissertation, Aligarh Muslim University.

[31] Pant, N.C., Kumar, S., Panday, M., Bajaj, A.K., Kandu, A., Joshi, S. and Shimyaphy, R.V.S. (2015) New Insights on the Genesis and Controls of Mineralization in Khetri Copper Belt and Adjacent Low Grade $\mathrm{Cu}$ Mineralization, Northwestern Indian Shield. Geological Survey of India, Special Publication, 101, 109-128.

[32] Das Gupta, S.P. (1970) Sulfide Deposits of Saladipura, Khetri Copper Belt, Rajasthan. Economic Geology, 65, 331-339. https://doi.org/10.2113/gsecongeo.65.3.331

[33] Ramdohr, P. (1955) Die Erzmineralien und ihre Verwachsungen. Akademie Verlag, Berlin.

[34] Schwartz, G.M. (1927) Intergrowths of Chalcopyrite and Cubanite: Experimental Proof of the Origin of Intergrowths and Their Bearing on the Geologic Thermometer. Economic Geology, 22, 44-61. https://doi.org/10.2113/gsecongeo.22.1.44

[35] Buerger, N.W. and Buerger, M.J. (1934) Crystallographic Relations between Cubanite Segregation Plates, Chalcopyrite Matrix and Secondary Chalcopyrite Twins. American Mineralogist, 19, 289-303.

[36] Edwards, A.B. (1954) Textures of the Ore Minerals and Their Significance. Australasian Inst. Mining and Met.

[37] Einaudi, M.T. (1977) Environment of Ore Deposition at Cerro De Pasco, Peru. Economic Geology, 72, 893-924. https://doi.org/10.2113/gsecongeo.72.6.893

[38] Wu, I. and Peterson, U. (1977) Geochemistry of Tetrahedrite and Mineral Zoning at Casapalca, Peru. Economic Geology, 72, 993-1016. https://doi.org/10.2113/gsecongeo.72.6.993

[39] Knight, L.E. (1977) A Thermochemical Study of Alunite, Enargite, Luzonite, and Tennantite Deposits. Economic Geology, 72, 1321-1336. https://doi.org/10.2113/gsecongeo.72.7.1321

[40] Spurrell, F.C.J. (1895) Notes on Egyptian Colours. Archaeological Journal, 52, 222-239. https://doi.org/10.1080/00665983.1895.10852669 
[41] Anthony, J.W., Bideaux, R.A., Bladh, K.W. and Nichols, M.C. (1990) Handbook of Mineralogy, Volume I. Elements, Sulfides, Sulfosalts. Mineral Data Publishing, Tucson, 588.

[42] Hurlbut, B.J. (1985) Experimental and Computational Investigation of Strain-Softening in Concrete. Doctoral Dissertation, University of Colorado, Denver.

[43] Li, X.C., Zhou, M.F., Williams-Jones, A.E., Yang, Y.H. and Gao, J.F. (2018) Timing and Genesis of $\mathrm{Cu}-(\mathrm{Au})$ Mineralization in the Khetri Copper Belt, Northwestern India: Constraints from in Situ U-Pb Ages and Sm-Nd Isotopes of Monazite-(Ce). Mineralium Deposita, 1-16. 